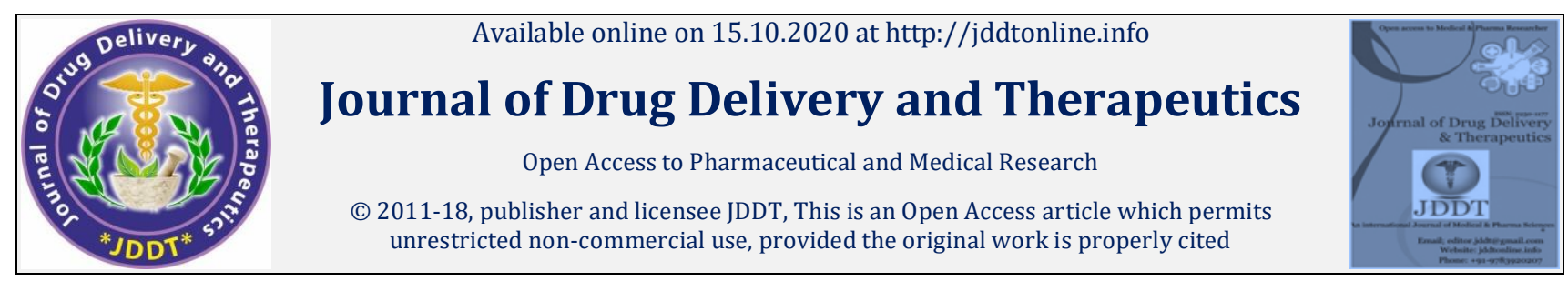

Open 1 Access

Review Article

\title{
Review on Antityrosinase Activity of Some Indian Medicinal Plants and their Phytoconstituents
}

\author{
Gupta Ruchi *, Saxena Rajiv, Patidar Archana, Chourasiya Yashu, Malviya Neelesh \\ Smriti College of Pharmaceutical Education, Indore (M.P.), India
}

\begin{abstract}
Tyrosinase (polyphenolic oxidase) is a multifunctional and copper containing enzyme. Tyrosinase is an enzyme which is responsible for melanin biosynthesis which is responsible for color of the skin. Melanin is synthesised in melanocyte cells by melanogenesis process. Melanogenesis protects skin surface from harmful ultraviolet radiations. Melanin is mainly synthesized in plants, micro organisms and mammalian cells. Melanin pigment is responsible for hyperpigmentation and hypopigmentation. When melanin is present in very less amount it causes local vitiligo and posttraumatic hypopigmentation. When melanin is present in very less amount it causes local vitiligo and posttraumatic hypopigmentation. Abnormal amount of melanin deposit in the specific sites of skin causes abnormal skin colored patches like solar lentigos, chloasma, freckles, post inflammatory hyperpigmentation etc. Tyrosinase is also responsible for color changes in fruits due to enzymatic reactions. Tyrosinase inhibitor compounds are used in cosmetics, food, agriculture science and also used in remedy for imbalance in pigmentations. Some Indian herbal plants and agents like Aloe barbedensis, Crocus sativus, Curcuma longa, Camellia sinensis, Glycyrrhiza glabra, Glycine max, Nelumbo nucifera, Hemidesmus indicus, Vitis Vinifera, Broussonetia papyrifera, resorcinol, arbutin, kojic acid, hydroquinone and ascorbic acid have antityrosinase enzymatic activity. So these plants and inhibitory agents are used in cosmetic industries due to their tyrosinase inhibitory effects or antityrosinase activity or antihyperpigmentation effects.
\end{abstract}

Keywords: Anti-hyperpimentation, Tyrosinase Inhibitor, Melanin, Herbal drugs.

Article Info: Received 08 Aug 2020; Review Completed 06 Sep 2020; $\quad$ Accepted 16 Sep 2020; Available online 15 Oct 2020

Cite this article as:

Gupta R, Saxena R, Patidar A, Chourasiya Y, Malviya N, Review on Antityrosinase Activity of Some Indian Medicinal Plants and their Phytoconstituents, Journal of Drug Delivery and Therapeutics. 2020; 10(5-s):199-204

http://dx.doi.org/10.22270/jddt.v10i5-s.4330

*Address for Correspondence:

Gupta Ruchi, Smriti College of Pharmaceutical Education, Indore (M.P.), India

\section{Introduction}

Tyrosinase (polyphenolic oxidase) is a multifunctional and copper containing enzyme. Tyrosinase is an enzyme which is responsible for melanin biosynthesis which is responsible for the color of the skin. Melanin is synthesized in melanocyte cells by melanogenesis process. Melanogenesis protects the skin surface from harmful ultraviolet radiations. Melanogenesis is also inhibited by tyrosinase inhibition, avoiding of UV radiation, inhibition of proliferation and metabolism of melanin in melanocyte cells 1 . Melanin enzyme is responsible for hyperpigmentation and hypopigmentation. When melanin is present in very less amount it causes local vitiligo and posttraumatic hypopigmentation. Abnormal amounts of melanin deposit in the specific sites of skin causes abnormal skin colored patches like solar lentigos, chloasma, freckles, post inflammatory hyperpigmentation, freckles etc. ${ }^{2}$.

Melanogenesis process by Involvement of Tyrosinase Enzyme.

Melanin is a pigment which is responsible for the color of the skin and pigmentation. Melanin composed of pheomelanin (yellow or red brown color), DHICA (enriched eumelanin, light brown), DHI (eumelanin, blue, black color). 


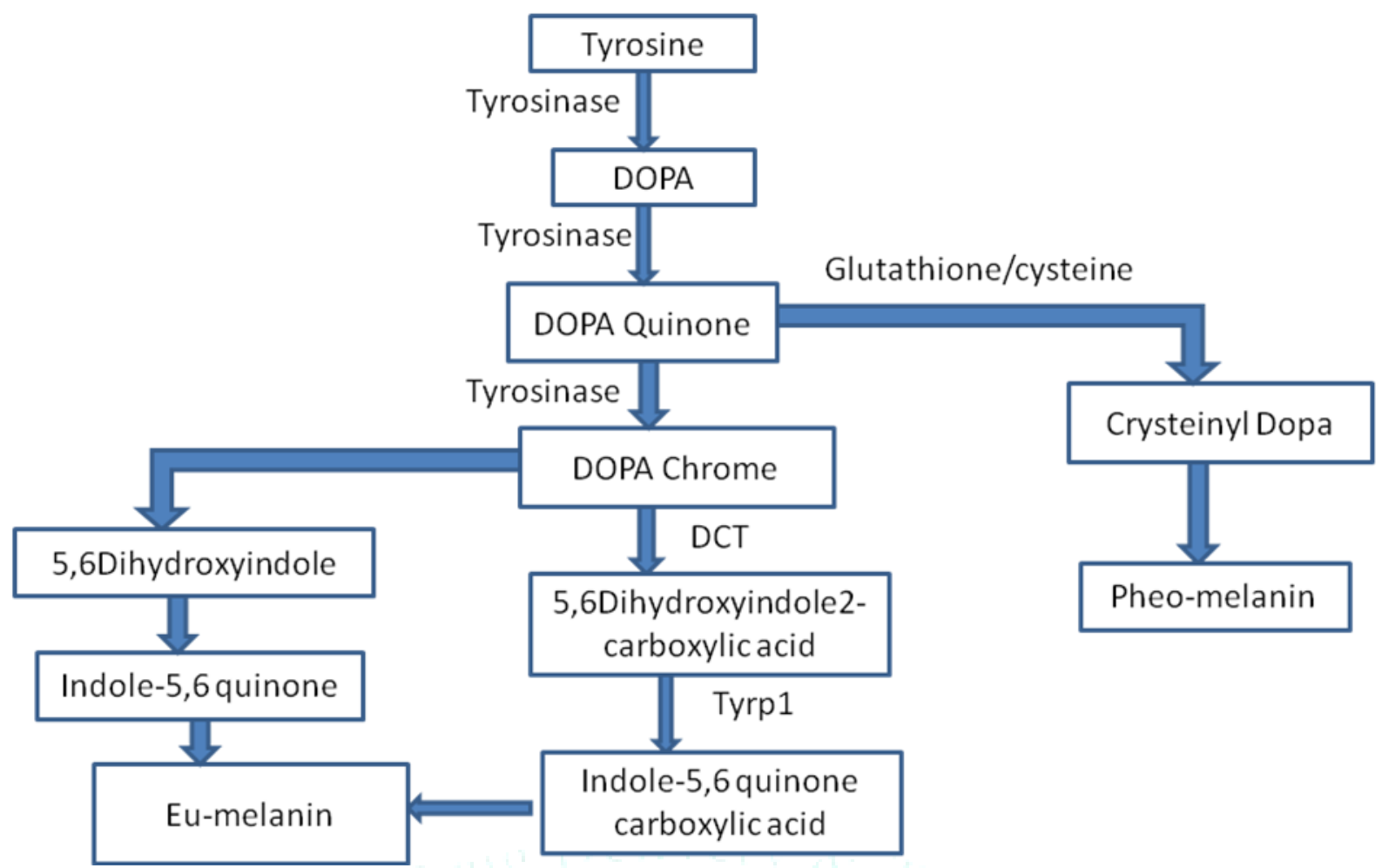

Figure1: Melanin biosynthesis by Tyrosinase enzyme

\section{Hperpigmentation Disorders and its Causes}

\section{$>$ Solar lentigos}

Solar lentigos is also known as Actinic lentigos or age spot which is caused by chronic exposure of skin to UV radiations causing inflammation. Solar lentigos mainly affects the skin of hands, arms and faces which are generally exposed to sun. It results in darkness of exposed areas of the skin. It is identified by histological analysis of darken area and normal area of the skin. These observations indicate changes in melanocytes within the darken area as compared to melanocytes in normal skin. The Actinic lentigos site has increased level of Tyrosinase enzyme, Tyrosinase related protein-1 (TYRP1), Dopachrome tautomerase (DCT), Microphthalmiaassociated transcription factor (MITF) etc. Epidermal endothelin cascade factor and stem cell factor both are responsible for the hyperpigmentation in case of solar lentigos ${ }^{3,4}$. Even when UV light is avoided some spots persist permanently due to, alteration of epidermalmelanin axis and factor XIII1 melanophages ${ }^{5}$.

\section{$>$ Chloasma}

Chloasma is also known as melasma. This is also caused when body parts are exposed to sunlight or UV light which causes hyperpigmentation. This condition has become worse in summer season. Chloasma is also caused by hormonal disturbance (progesterone, during pregnancy), hormonal birth control pills (depends upon extravascular macrophages), stimulation of $\alpha$-melanocyte-stimulating hormone (keratinocyte cells) and stem cell factors (fibroblast cells) these all factors are responsible for melasma ${ }^{3,6}$.

\section{$>$ Freckles}

Exposure of particular parts of the body to sunlight is responsible for Freckles, which causes small brown patches on the skin. It is mostly depended upon the epidermal melanin. It also depends upon climate (darken in the summer and lighten in winter).

\section{$>$ Post Inflammatory Hyperpigmentation}

Post inflammatory Hyperpigmentation is also caused in sites of skin exposed to UV radiation after the inflammation caused in sunburn sites. This is identified by histopathological analysis of the inflammatory site of the skin. This sunburn inflammation mainly depends upon the stimulation of melanocyte cells by some mediators like IL-1$\mathrm{x}$, endothelin- 1 and stem cell factor $7,8,9,4$. Some time reactive oxygen species like nitric oxide and superoxide (secreted by the inflammatory cells in damaged skin) may stimulate melanocyte cells. Additionally, some damaged epidermal cells can secrete the endocrine inducer pigments like melanocyte stimulating hormones which is responsible for the hyperpigmentation in UV exposed area of the skin. Post inflammatory hyperpigmentaion is a lifelong skin problem in which melanin is produced in the inflammatory damaged skin cells which enters in the dermis where it is engulf by macrophages resulting in production of melanophages ${ }^{10}$.

\section{Some Depigmenting Agents and their action}

Many processes are involved in the formation of pigment in the skin. This is called melanogenesis (synthesis of melanin pigments). This synthesis involves the action of tyrosinase enzyme. Depigmenting agents have different types of mechanism of action for an antihyperpigmentaion activity so there is a wide array of target against which to screen for pigmentation control agents ${ }^{11,12}$.

Among various depigmenting agents which work by different mechanisms of action like by inhibition of melanin enzyme synthesis (tyrosinase, tyrosinase protein 1 and 2) by inhibition of melanocyte stimulating (by anti inflammatory agents, antioxidant), by inhibition of melanosomes transport 
within the melanocyte. But this review mainly focuses on tyrosinase Inhibition agent (some agents like hydroquinone, kojic acid, resorcinol, ascorbic acid, arbutin, ellagic acid and sulfhydryl) which is involved in inhibition of conversion of tyrosine to melanin synthesis ${ }^{12,14}$. Several depigmenting agents work through different mechanisms of action which is mentioned in Figure 2 and Table no. 1.

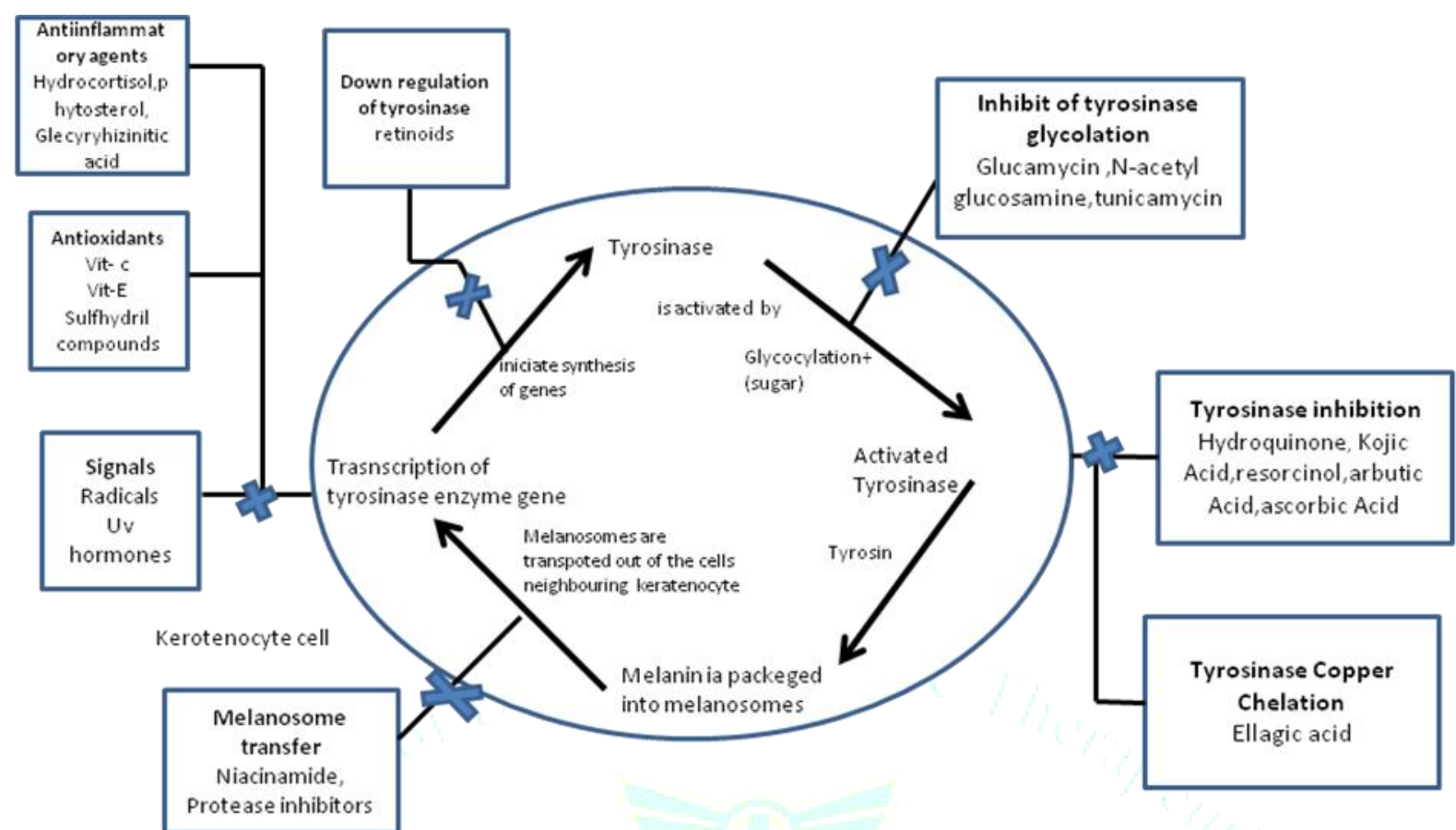

Figure2: The cycle of mechanisms of action of various Depigmenting Agents

Table 1: Some Depigmenting Agents and their mechanisms of action

\begin{tabular}{|l|l|l|}
\hline S.no. & Mechanism of Depigmenting Agents & Example of Depigmenting Agents \\
\hline A. & Inhibition of Tyrosinase enzyme & Hydroquinone, resorcinols, kojic acid, arbutin, ascorbic acid (vitamin C) \\
\hline B. & Copper chelation of Tyrosinase enzyme & Ellagic acid \\
\hline C. & $\begin{array}{l}\text { Inhibition of glycosylation of enzyme } \\
\text { tyrosinase }\end{array}$ & Glucosamine, $N$-acetyl glucosamine, tunicamycin \\
\hline D. & Transfer of Melanosome & Niacinamide, protease inhibitors \\
\hline E. & Tyrosinase Down regulation & Retinoid \\
\hline F. & Antioxidant & Vitamin C compounds, vitamin E, sulfhydryl compounds \\
\hline G. & Anti-inflammatory agent & Hydrocortisone, phytosterol, glycyrrhetinic acid \\
\hline
\end{tabular}


Table 2: Few examples of botanical extracts with De-pigmenting Activity 38

\begin{tabular}{|c|c|c|}
\hline Component & Plant source & Depigmenting Mechanism \\
\hline $\begin{array}{l}\text { Arbutins }, \alpha-\text { Arbutin, } \\
\text { Deoxyarbutin }\end{array}$ & $\begin{array}{l}\text { Pear, cranberry, blueberry, bearberry } \\
\text { shrub }\end{array}$ & $\begin{array}{l}\downarrow \text { Tyr. } \\
\downarrow \text { DHICA polymerase }\end{array}$ \\
\hline Aloesin & Aloe & $\begin{array}{l}\downarrow \text { Tyr. } \\
\text { Competitively } \\
\downarrow \text { DOPA oxidase }\end{array}$ \\
\hline \multicolumn{3}{|l|}{ Flavonoids } \\
\hline Flavones & Most plants & $\begin{array}{l}\downarrow \text { Tyr. } \\
\text { Uncompetitively }\end{array}$ \\
\hline Flavonols & Most plants & Copper chelation \\
\hline Hesperidin & Citrus fruits & $\begin{array}{l}\downarrow \text { Tyr. } \\
\text { Antioxidant of collagen }\end{array}$ \\
\hline p-Coumaric acid & Panax ginseng & $\downarrow$ L-tyrosine oxidation \\
\hline Niacinamide & Root vegetables, yeast & $\begin{array}{l}\downarrow \text { Melanin transfer, antioxidant } \\
\text { of collagen }\end{array}$ \\
\hline \multicolumn{3}{|l|}{ Licorice extracts } \\
\hline Glabridin & Licorice & $\begin{array}{l}\downarrow \text { Tyr. } \\
\text { ROS scavenger }\end{array}$ \\
\hline Liquiritin & Licorice & $\begin{array}{l}\text { Melanin dispersibility } \\
\text { Epidermal remove }\end{array}$ \\
\hline Mulberry & Morus alba & $\begin{array}{l}\downarrow \text { Tyr. } \\
\text { ROS scavenger }\end{array}$ \\
\hline \multicolumn{3}{|l|}{ Polyphenols } \\
\hline Procyanidins & Grape seeds, cranberry & $\begin{array}{l}\downarrow \text { Tyr. } \\
\text { ROS scavenger }\end{array}$ \\
\hline Ellagic acid & Strawberry, geranium & $\begin{array}{l}\text { Copper chelation } \\
\downarrow \text { MC proliferation }\end{array}$ \\
\hline \multicolumn{3}{|c|}{ Traditional Chinese medicine } \\
\hline Sophorcarpidine & Kuhseng & $\downarrow$ Tyr. \\
\hline
\end{tabular}

$\downarrow$ Inhibit, DHICA:5,6-dihydroxyindole-2-carboxylic acid, DOPA:3,4-dihydroxyphenylalanine, HQ:hydroquinone; KC: keratinocyte, MC: melanocyte, Tyr: Tyrosinase

\section{Some plants and their constituents have Tyrosinase Inhibitory activity.}

Numerous plants have tyrosinase inhibitory activity and they have been used in the treatment of Skin Pigmentation Disorder. So these drugs are used as a de-pigmenting agents. Some of potential drugs are mentioned, discussed here as:

\section{Aloe}

It belongs to liliaceae family and this drug is mainly used in cosmetic industries as skin whitening agents. It contains aloesin and 2-o-ferulonyaloesin isolated from aloe arborescens mill. These constituents show mushroom tyrosinase inhibition activity ${ }^{15,16}$. They have synergistic action with arbutin for inhibition of melanin production $16,39,40$. Combination therapy of aloesin and arbutin is useful in UV mediated hyperpigmentation ${ }^{17}$.

\section{Crocus sativus}

It is also known as spice saffron and it has belonged to Iridaceae family. It is mainly used as skin whitening agents. Kaempferol, its 3-o glycoside derivative and flavonols (quercetin 3-o-glycoside) are isolated from the fresh flowers of crocus sativus and tyrosinase inhibitory activity is investigated in mushroom ${ }^{18}$. Inhibition of Diphenolase is due to crocin obtained from stigmas of Crocus sativus, but studies showed that the affinity specifically to mushroom tyrosinase was less ${ }^{19}$.

\section{Curcuma longa}

It belongs to Zingiberaceae family. It is also known as turmeric. Rhizome powder of Curcuma longa is present in Ayurvedic semisolid preparations which are called "Uptan" that enhances the color of the skin ${ }^{22,20 . ~ C u r c u m i n ~ a n d ~}$ curcuminoids phytoconstituents are isolated from Curcuma longa which shows tyrosinase inhibitory activity in mushroom. Curcumin as compared to curcumin-bis- $\beta$-Dglycoside shows less tyrosinase inhibition potential 21,23 . 


\section{Camellia sinensis}

It comes under theaceae family, which is also called as Green tea. Tea extract content Polyphenols, $(-)$ epicatechin, $(+)$ catechin, (-) epicatechin3-o-gallate (ECG) and (-) epigallocatechin 3-0- gallate (EGCG) were investigated on mushroom tyrosinase inhibitory activity (monophenol inhibition). Gallic acid along with epigallocatechin 3-0gallate, (-) epicatechin3-o-gallate and Catechin polyphenolic compound tested in B16 melanoma cells so all these inhibited melonogenesis by inhibition of tyrosinase protein except catechin. The study on the depigmentation potential study on inhibition of enzyme and murine cell-line analysis showed that the depigmentation activity is due to flavones that contains a 3-position gallic acid moiety ${ }^{24}$.

\section{Glycyrrhiza glabra}

It comes under fabaceae family and it is also called as liquorice. It is also used in cosmetic preparation in skin whitening agents. It contains glabridin which shows anti melanogenesis activity (on B16 murine melanoma cells), tyrosinase inhibitory activity (due to the presence of hydroxyl groups at 2 and 4 position) and also inhibition of UVB induced pigmentation and inflammation in guinea pig $\operatorname{skin}^{25}$.

\section{Glycine max}

It comes under fabaceae family and it is called as Soybean. It is mainly used as nutraceutical in dietary supplements. It is a good source of antioxidant such as $\gamma$-tocopherol, isoflavones, flavonols, flavan-3-ols, proanthocyanidins and anthocyanins. It has tyrosinase inhibitory potential 26 . Soyabean seed extracts contain two proteinase inhibitors i.e. Kunitz-type trypsin inhibitor (soybean trypsin inhibitor) and BowmanBirk protease inhibitor. These inhibitors have been explored as depigmenting agents. The inhibition mechanism mainly responsible is phagocytosis of keratinocyte and melanin distribution (in dark-skinned Yucatan swine) which shown to reduced pigmentation ${ }^{27}$.

\section{Nelumbo nucifera}

It comes under nelumbonaceae and it is also called as lotus. According to Ayurveda it has a lot of medicinal properties ${ }^{28}$. Phytochemical and pharmacological studies show the diverse role of this medicinal herb ${ }^{29}$. Aqueous extract of leaf, seed and flower from Nelumbo nucifera shown to possess DOPA-oxidase inhibition effect or in other words whitening effect. This shows that Nelumbo nucifera has whitening effect and anti-wrinkle effect on the skin ${ }^{30}$.

\section{Vitis vinifera}

Vitis vinifera is also called as "wine grape" and grapevine. Phenolic compounds are mostly present in grape's skin, pulp and seeds. Compared to other plant parts, a higher number of phenols are present in seeds ${ }^{31}$. Polyphenols (proanthocyanidins) of grape seed shows free radical scavenging activity and reduced hyper pigmentation in female melasma patients ${ }^{32}$.

\section{Hemidesmus indicus}

It comes under Asclepiadaceae family and it is also called as Anantmul.it has a strong and persistent fragrance 33 . Phenolic compound 2-hydroxy-4- methoxybenzaldehyde is the main component of $\mathrm{H}$. indicus. It shows inhibitory action against tyrosinase's biphenolase activity. Monophenolase activity can be inhibited more effectively by 2-hydroxy-4methoxybenzaldehyde as compared to vanillin ${ }^{34,35}$.

\section{Broussonetia papyrifera}

It comes under Moracea family and it is also called as "Mulberries". Its leaf and root extracts shows antimelanogenic properties. Chloroform extracts of B. papyrifera (flavones, uralenol, quercetin and broussoflavonol) have better mushroom tyrosinase inhibitory activity when compared to arbutin. Isoliquiritigenin isolated from plant Broussonetia papyrifera demonstrated weak tyrosinase inhibitor potential as compared to arbutin and kojic acid 36 .

\section{Conflict of Interest}

The authors declare there is no conflict of interest.

\section{REFERENCES}

1. Wang $\mathrm{KH}$, Lin RD., Hus FL, Huang YH, Chang HC, Huang CY, Lee $\mathrm{MH}$, "Cosmatic application of selected traditiol chinece herbal medicines" Journal of Ethnopharmacology, 2006;106:353-359.

2. Solano F, Briganti S, Picardo M, Ghanem G, "Hypopigmenting agent: an updated review on biological,chemical and clinical aspect" Pigment cell research, 2006; 19(6):550-71.

3. Imokawa G, Nordlund JJ, Boissy RE, Hearing VJ, King RA, Oetting WS, Ortonne JP.eds "Paracrine interactions of melanocytes in pigmentary disorders. In:The pigmentary system $2^{\text {nd }}$ ed. Malden, MA: Blackwell Publishing, 2006; 42144.

4. Kadono S, Manaka I, kawashima M, Kobayashi T, Imokawa G, "The role of the epidermal endothelin cascade in the hyperpigmentation mechanism of lentigo senilis" J Invest Dermatol, 2001; 116:571-577

5. Unver N, Freyschmidt-Paul, Horster S, Wenck H, Stab F,Blatt T et al. "Alteration in the epidermal-dermal melanin axis and factor XIIIa melanophages in senile lentigo and ageing skin" $\mathrm{Br}$ J Dermatol, 2006; 155:159-128.

6. Motakawa T, Matsunaga J, Tomita Y, "Messenger RNA levels of melanogenesis-associated genes in lentigo senilis lesions pigmentary disorder" Pig Cell Res, 2005; 17:96-110.

7. Kang HY, Hwang JS, Lee JY, Ahn JH, Kim JY, Lee ES et al. "The dermal stem cell factor and c-kit are overexpressed in melasma" Br J Dermatol, 2006; 154:1094-1099.

8. Gilchrest BA, Park HY, Eller MS, Yaar M, "The photobiology of the tanning respons. In: the pigmentary system" $1^{\text {st }}$ ed. New York: Oxford University Press, 1998; 359-372.

9. Abdel MZ, Kadekaro AL, Nordlund JJ, Boissy RE, Hearing VI, King RA, Oetting WS, Ortonne JP. eds "Human pigmentation: its regulation by ultraviolet light and by endocrine, paracrine and autocrine faction. The pigmentary system" $2^{\text {nd }}$ ed. Malden, MA: Blackwell Publishing, 2006; 410-420.

10. Sriwiriyanont P, Ohuchi A, Hachiya A, Visscher MO, Boissy RE, "Interaction between stem cell factor and endothelin-1: effect on melanogenesis in human skin xenografts" Lab Invest, 2006; 86:1115-1125.

11. Halder RM, Nordlund JJ, "Topical treatment of pigmentary disorders The pigmentary system" 2nd ed, Malden, MA, Blackwell Publishing, 2006; 1165-1174.

12. Boissy RE, " Melanosome transfer to and translocation in the Keratinocyte" Exp Dermatol, 2003; 12s:5-12.

13. Nakayama H, Ebihara T, Satoh N, Jinnai T. "Depigmentation agents. In: Cosmeceuticals and active cosmetics" Boca Raton: Taylor \& Francis, 2005; 185-205.

14. Ortonne JP, Donald L, "Bissett Latest Insights into Skin Hyperpigmentation Journal of Investigative Dermatology Symposium Proceedings" 2008; 13:10-14.

15. Land EJ, Ramsden CA, Riley PA, "Toxicological aspects of melanin and melanogenesis, The pigmentary system second" Malden ,MA, Blackwell Publishing 2006; 354-394

16. Yagi A, Kanbara T, Morinobu N. "Inhibition of mushroom tyrosinase by Aloe extract" Plant Med, 1987; 53:515-517.

17. Jin YH, Lee SJ, Chung MH, Park JH, Park YI, Cho TH, Lee SK, "Aloesin and arbutin inhibit tyrosinase activity in a synergistic manner via a different actionmechanism" Arch. Pharm. Res. 1999; 22:232-236. 
18. Choi S, Lee SK, Kim JE, Chung MH, Park YI. “Aloesin inhibits hyperpigmentation induced by UV radiation" Clin. Exp. Dermatol. 2002; 27:513-515

19. Kubo I, Kinst-Hori I, "Flavonols from saffron flower: tyrosinase inhibitory activity and inhibition mechanism" J. Agric. Food Chem. 1999; 47:4121-4125.

20. Patil S, Srinivas S, Jadhav J. "Evaluation of crocin and curcumin affinity on mushroom tyrosinase using surface plasmon resonance" Int. J. Biol. Macromol. 2014; 65:163-166.

21. Dixit U, Goyal VC. "Traditional Knowledge from and for elderly. Indian" J. Tradit. Knowl, 2011; 10(3):429-438.

22. Du ZY, Jiang YF, Tang ZK, Mo RQ, Xue GH, Lu YJ, Zheng X, Dong, CZ, Zhang K. "Antioxidation and tyrosinase inhibition of polyphenolic curcuminanalogs" Biosci.Biotechnol. Biochem, 2011; 75:2351-2358.

23. Mukherjee PK, "Evidence-Based Validation of Herbal Medicine" Elsevier, USA, 2015; 119-148.

24. Prasad E, Hameeda B, Rao AB, Reddy G, "Biotransformation of curcumin for improved biological activity and antiproliferative activity on acute HT-29 human cell lines" Indian J. Biotechnol, 2014; 13:324-329.

25. Sato K, Toriyama $M$, "Depigmenting effect of catechins. Molecules" 2009; 14(11):4425-4432.

26. Yokota T, Nishio H, Kubota Y, Mizoguchi M, "The inhibitory effect of glabridin from licorice extracts on melanogenesis and inflammation" Pigment. Cell Res, 1998; 11:355-361.

27. Correa CR, Li L, Aldini G, Carini M, Chen CYO, Chun HK, Cho SM, Park KM, Russell RM, Blumberg JB, Yeum KJ. "Composition and stability of phytochemicals in five varieties of black soybeans (Glycine max)" Food Chem, 2010; 123:1176-1184.

28. Paine C, Sharlow E, Liebel F, "An alternative approach to depigmentation by soybean extracts via inhibition of the PAR2 pathway" J. Invest. Dermatol, 2001; 116:587-595.

29. Paudel KR, Panth N, "Phytochemical profile and biological activity of Nelumbo nucifera" Evid. Complement. Alternat. Med, 2015; 789124.

30. Mehta NR, Patel EP, Patani PV, Shah, "NelumboNucifera (Lotus): A Review on Ethanobotany, Phytochemistry and Pharmacology" Indian J. Pharm. Biol. Res, 2013; 1:152-167.
31. Kim T, Kim HJ, Cho SK, Kang WY, Baek H, Jeon HY, Kim B, Kim D. "Nelumbonucifera extracts as whitening and anti-wrinkle cosmetic agent" Korean J.Chem. Eng, 2011; 28:424-427.

32. Hsu CK, Chou ST, Huang PJ, Mong MC, Wang CK, Hsueh YP, Jhan JK, "Crude ethanol extracts from grape seeds and peels exhibit anti-tyrosinase activity" J. Cosmet. Sci, 2012; 63:225232.

33. Ribeiro AS, Estanqueiro M, Oliveira M, Lobo JMS, "Main benefits and applicability of plant extracts in skin care products" Cosmetics 2015; 2:48-65.

34. Jain SK, Medicinal Plants. National Book Trust, New Delhi, 1994; 95-96.

35. Das S, Bisht SS, "The bioactive and therapeutic potential of Hemidesmus indicus R.Br. (Indian Sarsaparilla) root" Phytother. Res, 2013; 27:791-801.

36. Kundu A, Mitra A, "Evaluating tyrosinase (monophenolase) inhibitory activity from fragrant roots of Hemidesmus indicus for potent use in herbal products" Ind.Crops Prod, 2014; 52:394-399.

37. Zheng ZP, Cheng K W, Chao J, Wu J, Wang M, "Tyrosinase inhibitors from paper mulberry (Broussonetia papyrifera)" Food Chem, 2008; 106:529-535.

38. Chun W, Li, Xu, Yuancheng W, Hu, C, Xianzhi H, "Determination of total polyphenol content and antityrosinase capacity of mulberrymedicine (Morus nigra L.) extract" Afr. J. Biotechnol, 2011; 10:16175-16180.

39. Wenyuan Zhu Jie Gao, "The Use of Botanical Extracts as Topical Skin-Lightening Agents for the Improvementof Skin Pigmentation Disorders, Journal of Investigative Dermatology Symposium Proceedings, 2008; 13.

40. Wu B, Zhang $\mathrm{X}, \mathrm{Wu} \mathrm{X}$, "New lignan glucosides with tyrosinase inhibitory activities from exocarp of Castanea henryi" Carbohydr. Res., 2012, 355:45-49.

41. Wu X, Yin S, Zhong J, Ding W, Wan J, Xie Z . "Mushroom tyrosinase inhibitors from Aloe barbadensis Miller" Fitoterapia, 2012; 83:1706-1711. 